\title{
Evaluation of salinity intrusion in arable lands of Al-Batinah coastal belt using unmanned aerial vehicle (UAV) color imagery
}

"Sawsana Hillal Al-Rahbi, Yaseen Ahmed Al-Mulla, Hemanatha Jayasuriya

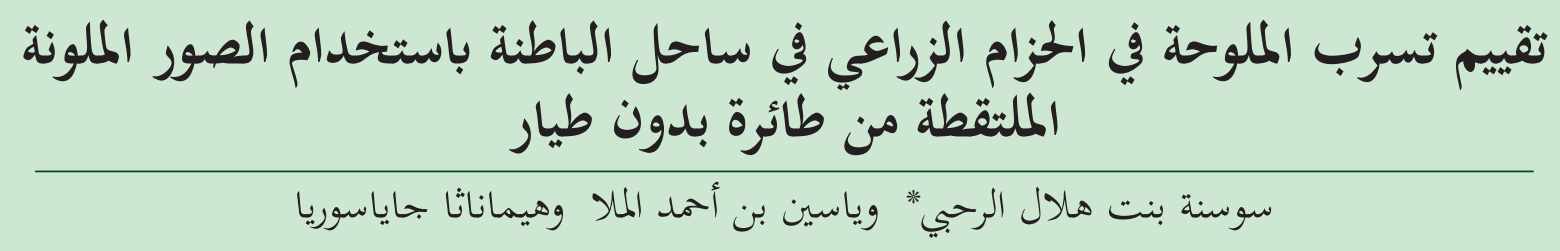

ABSTRACT. Salinity by seawater intrusion due to excess groundwater pumping for irrigation is a major environmental challenge in the coastal areas of the Sultanate of Oman. Increasing salinity levels moving inward the arable lands is happening in a rapid manner. Thus, salinity needs to be evaluated and quantified using a fast and accurate method. The objective of this study was to estimate salinity intrusion in Al-Batinah coastal belt using color aerial imaging. The study was conducted in five randomly selected sites at increasing distances from the seashore of Al-Suwaiq area in Al-Batinah region of northern Oman. Color aerial images were acquired for each site with an Unmanned Aerial Vehicle (UAV). Images were enhanced by orthorectification in ENVI software. A Green Leaf Index (GLI) was obtained from each site image using Matlab software. Image analysis results were compared with the results of analyzed soil and water samples taken for ground-truth verification. There was a strong negative correlation between the distance from the seashore and the soil EC of each site $(R=-0.95)$. Similarly, the mean value of GLI increased as the salinity levels decreased, $R=-0.96$ and -0.92 for soil EC and water EC, respectively. We demonstrated the possibility of the use of color images taken by a UAV to accurately quantify the effect of soil salination on vegetation along the costal belt.

KeYwords: Seawater Intrusion; Salinity Dynamics; UAV; Image Processing; GLI.

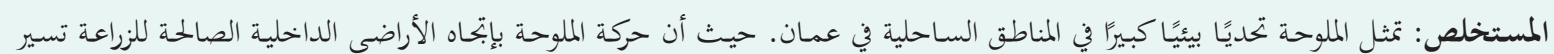

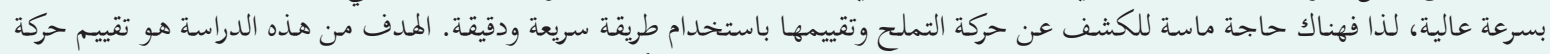

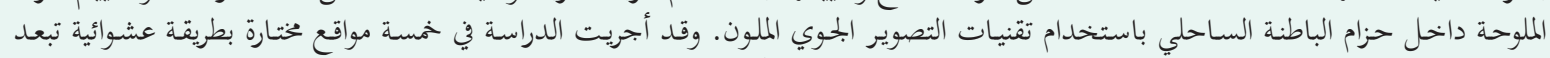

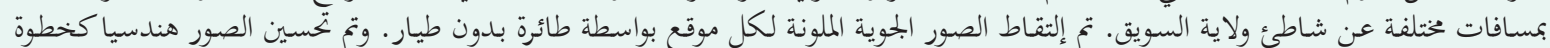

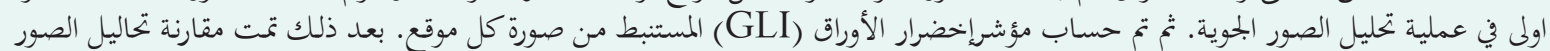

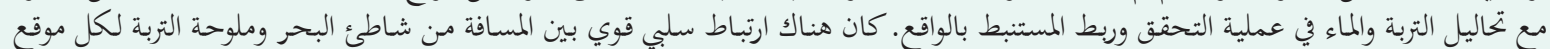

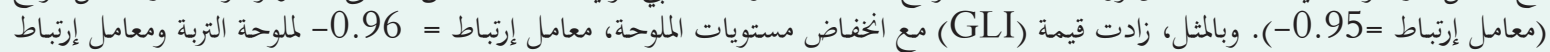

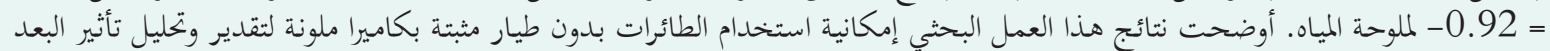

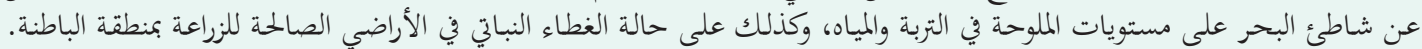

$$
\text { الكلمات المفتاحية: تسرب الملوحة، ديناميكية التملح، الطائرات بدون طيار، تحليل الصور، مؤشر إخضرار الأوراق }
$$

\section{Introduction}

1 he Sultanate of Oman is considered as an arid country with an average annual rainfall of about $100 \mathrm{~mm}$. Although agriculture occupies about $5 \%$ of the total area of Oman distributed around eleven governorates (regions), the agricultural sector consumes more than $93 \%$ of the total water demand. Al-Batinah North governorate represents the largest area of Oman's agricultural lands (Table 1) covering 24\% of the total agricultural area of the country and is considered to be Oman's most important agricultural area as it produces $65 \%$ of the Omani agricultural production with crops such as dates, fruits, vegetables and forage crops such as alfalfa and Rhodes grass (Choudri et al. 2015a; Choudri et al. 2013).

"Sawsana Al-Rahbi ( $\backslash$ ) s.h.rahbi1@gmail.com, Department of Soils, Water and Agricultural Engineering, ollege of Agricultural and Marine Sciences, Sultan Qaboos University, Box 34, Al-Khod 123.
The population in Al-Batinah has sharply increased since 2003: i.e. by more than 100,000 people within 7 years. Subsequently, the socioeconomic activities; active ports, coastal tourism projects, industrial activities, infrastructure development, intensive agriculture and urbanization have been rapidly taken place in this coastal zone (Choudri et al. 2015c). Such activities are related to population growth and have led to increasing pressures on natural resources including groundwater, agriculture and land use (Lawley et al. 2016). It also has resulted in some environmental challenges such as seawater intrusion, water and soil salinition and desertification (Choudri et al. 2015a).

The management plans to mitigate the environmental challenges are constrained by the shortage of information about the interaction between the development activities and the environment (Rishi and Mudaliar 2014). In general, lack of information about the global, national and local land resources may lead to management plans 
without environmental concerns (Mulder et al. 2011). Thus, there is a necessity for accurate, cost-effective and timely monitoring method to update the information on the status changes in the arable lands of coastal area (Mishra 2014), in order to develop a framework for the decision makers to manage the environmental problems.

Bajjali (2003) has conducted a study to assess the ground water quality in Oman by analyzing 20,000 wells across different regions. The study indicated that Al-Batinah coast is the most affected area with groundwater salinity in Oman, where the water salinity ranges from 5 to $44 \mathrm{dS} / \mathrm{m}$ (Choudri et al. 2015c). As reported by Choudri et al. (2015b), Ministry of Regional Municipalities and Water Resources collected salinity data from 18 different wells in Al-Batinah region during the years 1991, 1993, 2005 and 2010 (Table 2). The collected data suggested that water salinity has increased gradually in all examined wells within the last two decades. Furthermore, water salinity is an important factor in soil salinity (Al-Belushi 2003; Hussain 2005). Approximately 52\% of Al-Batinah lands are affected by soil salinity (Al-Mulla et al. 2010). Between the years 2000-2005, the percentage of the agricultural lands affected with soil salinity has increased by about 7\% (Al Barwani and Helmi 2006). In addition, soil salinity is considered as one of the main reasons of desertification in arid and semi-arid regions and so in Al-Batinah coast particularly (Al-Belushi 2003; Choudri et al. 2015b). On the other hand, soil salinition is considered as one of the main reduction factors of Omani dates exportation which decreased by 2,000 MT within a 5-year period (2007-2011). Similarly, production of date palm in Al-Batinah region has steadily declined within the last few years mainly due to groundwater salinity (Al-Yahyai and Khan 2015).

Although there are many studies investigated the
Table 1. Area of the agricultural lands in each governorate of Sultanate of Oman (feddan)

\begin{tabular}{lll} 
Governorate & $\begin{array}{l}\text { Agricultural land } \\
\text { Area (feddan)* }\end{array}$ & Percentage \% \\
\hline Muscat & $11,555.85$ & 3.26 \\
Dhofar & $65,921.13$ & 18.57 \\
Musandum & 3,242 & 0.91 \\
Al Buraimi & $16,123.21$ & 4.54 \\
Ad Dakhiliyah & $45,732.97$ & 12.88 \\
Al Batinah North & $85,118.27$ & 23.98 \\
Al Batinah South & $48,984.53$ & 13.80 \\
Ash Sharqiyah South & $15,206.87$ & 4.28 \\
Ash Sharqiyah North & $27,523.27$ & 7.75 \\
Adh Dhahirah & $33,295.08$ & 9.38 \\
Al Wusta & $2,307.9$ & 0.65 \\
Total & $355,011.1$ & 100
\end{tabular}

*(M.A.F 2013)

salinity levels in Al-Batinah region using the traditional field visits and lab analysis, there is no documented evidences on evaluation of salinity change inward the coastal belt, and particularly using areal imaging technique. Therefore, the objective of this study was to analyze salinity change inward Al-Batinah coastal belt using images collected from an unmanned aerial vehicle (UAV) combined with color imaging techniques.

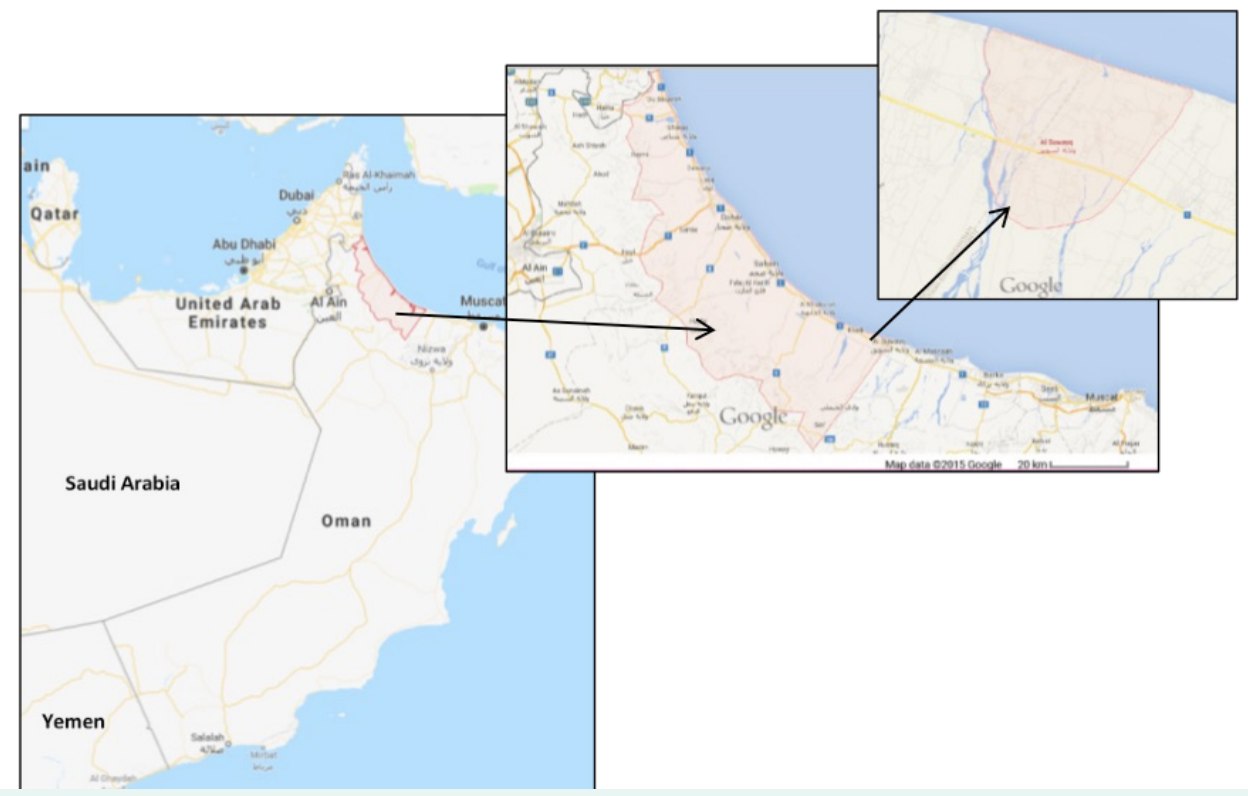

Figure 1. The Study Area location 


\section{Materials and Methods}

\section{Study Area}

The study was conducted in Al-Suwaiq area (23 $50^{\prime}$ $\left.58^{\prime \prime} \mathrm{N}, 57^{\circ} 26^{\prime} 19^{\prime \prime} \mathrm{E}\right)$. It is located at the south part of Al-Batinah North governorate (Fig. 1). The climate of Al-Suwaiq is characterized as dry with average annual humidity of $32 \%$ and high evapotranspiration rate. The average air temperature of the coastal area is $28.5{ }^{\circ} \mathrm{C}$ and $17.8{ }^{\circ} \mathrm{C}$ in the mountain area. The average rainfall rate in $\mathrm{Al}$-Suwaiq (as a part of Al-Batinah region) is 50 $\mathrm{mm}$ /year, varying in time and places within the region (Kwarteng et al. 2009) .

\section{Sites Selection}

Five sites were randomly selected within 0.3 to $6 \mathrm{~km}$ inland distance from the seashore of Oman through the agricultural land within the study area.

\section{Samples Collection and Analysis}

In each of the five randomly selected sites, five locations were selected randomly to collect soil samples. A Global Positioning System device (Garmin eTrex Legend Cx GPS, USA) was used to register each location coordinates. At each location, three soil samples were collected from three different depths; $5 \mathrm{~cm}, 20 \mathrm{~cm}$ and $50 \mathrm{~cm}$. Around $500 \mathrm{~g}$ of soil were taken with an auger to represent each depth. Each sample was kept in a clean plastic bag and annotated separately. A total of 75 soil samples were collected representing 5 sites $\times 5$ locations $\times 3$ depths. The saturation method was used to obtain soil extract from soil samples. Each soil extract was investigated for electrical conductivity (EC) which is expressed by deci-Siemens per meter $\left(\mathrm{dS} \mathrm{m}^{-1}\right)$. In addition, water samples (one sample from each site) were collected from the irrigation water sources (wells) of each site and were kept in a clean plastic container and transferred to the lab for analysis. The EC of each water sample were measured using EC meter.

\section{Image Acquisition}

Aerial images were taken by a digital color camera with 12.4 megapixels resolution. The camera was mounted on a quadcopter UAV (model: phantom-3-pro, DJI INC., China). Site images were taken from (130-275) $\mathrm{m}$ above the ground according to each site area. The captured images were saved in JPG format, which is a common format for realistic images and readable in different image processing softwares. The images were transferred to the computer to be analyzed.

\section{Image Analysis}

Orthorectification was conducted as a pre-processing technique in order to enhance the site images and to decrease image distortion. The Environment for Visualizing Images (ENVI) software (version 5.0.3, Exelis Visual Information Solutions INC., US) was used for image Orthorectification using Ground Control Points (GCPs) and Replacement Sensor Model (RSM). The GCPs were collected using Google Earth software (Version: 7.1.7.2600, Google INC.).

Several vegetation indices which depends only on color bands; Green Leaf Index (GLI), Visible Atmospherically Resistant Index (VARI) and Triangular greenness index (TGI). GLI has been commonly used in thresholding the green vegetation in aerial images of canopy scales (Chianucci et al. 2016; Hunt Jr et al. 2013; Macfarlane and Ogden 2012). Thus, GLI was computed (Eqn. 1) to determine canopy attributes within each site

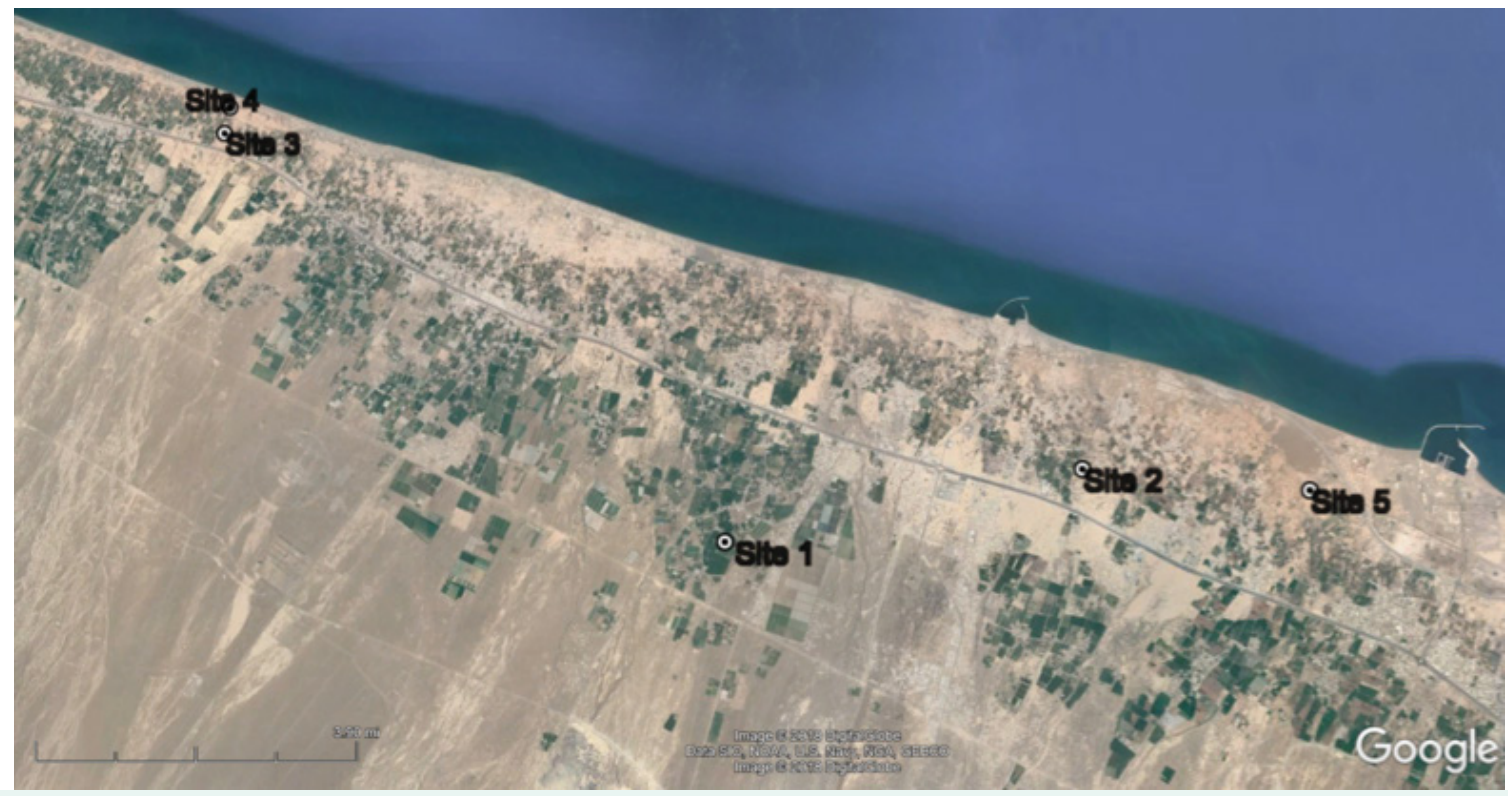

Figure 2. The locations of the selected sites 
Table 2. Location of salinity monitoring wells in Al-Batinah region with the observed salinity (ppm) in 1991, 1993, 2005 and 2010

\begin{tabular}{|c|c|c|c|c|c|c|}
\hline Well ID & $\begin{array}{l}\text { Location } \\
\text { (E) }\end{array}$ & $\begin{array}{l}\text { Location } \\
\text { (N) }\end{array}$ & $1991^{*}$ & $1993 \%$ & $2005^{*}$ & $2010 \%$ \\
\hline N-101 & 578701 & 2621460 & 1504 & 1632 & 2112 & 3072 \\
\hline N-92 & 582083 & 2620091 & 839 & 833 & 835 & 849 \\
\hline $\mathrm{T}-52$ & 584162 & 2622750 & 1606 & 2214 & 8262 & 12288 \\
\hline N-79 & 585655 & 2617956 & 800 & 931 & 1280 & 1798 \\
\hline B-49 & 586184 & 2622605 & 7379 & 8896 & 8979 & 9126 \\
\hline $\mathrm{T}-30$ & 591740 & 2621062 & 9280 & 9421 & 10682 & 14784 \\
\hline N-107 & 575993 & 2623943 & 1187 & 1112 & 5114 & 10432 \\
\hline B-70 & 571376 & 2627585 & 5440 & 6573 & 6144 & 11520 \\
\hline B-73 & 572962 & 2627174 & 7571 & 7424 & 8800 & 9728 \\
\hline B-83 & 568271 & 2628276 & 8410 & 6298 & 9600 & 12160 \\
\hline T-46 & 585991 & 2621972 & 6720 & 7507 & 13120 & 16576 \\
\hline $\mathrm{N}-63$ & 590404 & 2619803 & 1382 & 1312 & 5133 & 14656 \\
\hline B-31 & 594298 & 2620548 & 4032 & 4902 & 11494 & 11514 \\
\hline N-53 & 591385 & 2616842 & 1344 & 672 & 1293 & 1792 \\
\hline N-71 & 587411 & 2619729 & 1427 & 1267 & 1958 & 3590 \\
\hline N-111 & 568658 & 2623958 & 774 & 833 & 1760 & 1837 \\
\hline N-66 & 588832 & 2617526 & 2138 & 1760 & 1978 & 2323 \\
\hline T-85 & 569008 & 2627063 & 3994 & 3610 & 6278 & 8896 \\
\hline
\end{tabular}

"Observed salinity concentration (ppm\#)

$\# p p m=d S / m \times 640(E C=0.1$ to $5 \mathrm{dS} / \mathrm{m}), p p m=d S / m \times 800(E C>5 \mathrm{dS} / \mathrm{m})$

using MATLAB software (Version: 9.0.0.341360, Mathwork INC., USA).

\section{$\mathrm{GLI}=(2 \mathrm{G}-\mathrm{R}-\mathrm{B}) /(2 \mathrm{G}+\mathrm{R}+\mathrm{B})$}

Where G, R and B are the digital values (0-255) of the green, red and blue bands of each pixel . The GLI value of each pixel in the site image were calculated using equation 1 . The GLI values were reconstructed by applying the MATLAB function (inpaint_nans.m). Then, the GLI pixel values were averaged to get the GLI value of the whole image.

\section{Statistical Analysis}

Pearson correlation coefficient was calculated to compare soil and water EC of each site with site distance from seashore. Regression analysis were used to esti-

Table 3. The correlation coefficient of each salinity parameter

\begin{tabular}{|cc|}
\hline Salinity Parameter & Correlation Coefficient \\
Soil EC $(5 \mathrm{~cm})$ & -0.94992 \\
Soil EC $(20 \mathrm{~cm})$ & -0.87461 \\
Soil EC $(50 \mathrm{~cm})$ & -0.7105 \\
Water EC & -0.48239 \\
\hline
\end{tabular}

mate soil and water salinity using the distance from the seashore and the value of GLI.

The method followed in this paper is illustrated in Figure 3.

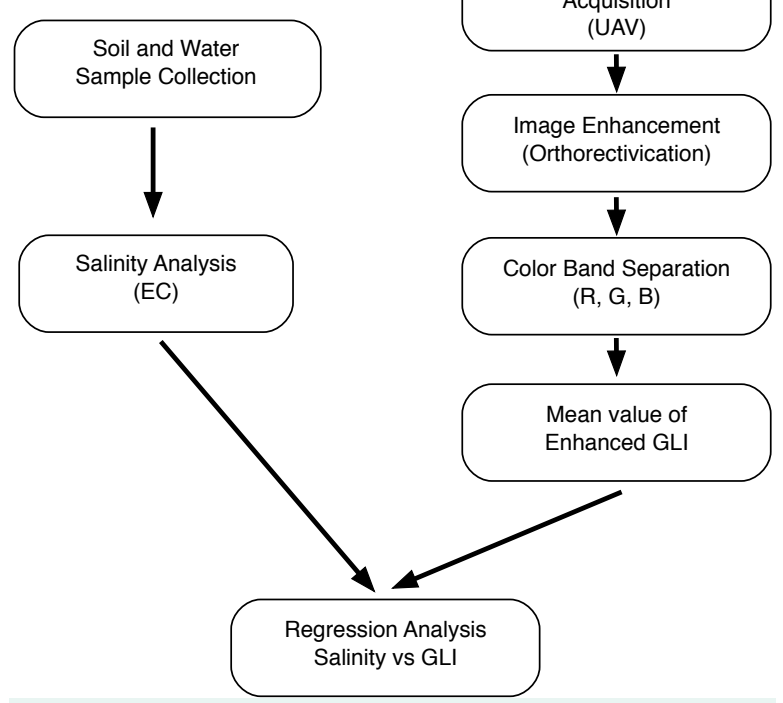

Figure 3. Soil EC (dS m-1) of each site (1-5) at different soil depths $(5,20$ and $50 \mathrm{~cm})$ 


\section{Results}

\section{Soil and Water Analysis}

The level of soil EC of the collected samples at different depths of 5,20 and $50 \mathrm{~cm}$ were decreased with the increase of the soil depth, as shown in Figure 4.

\section{Effect of Seashore on Salinity Levels}

The effect of site location from seashore on salinity levels is illustrated in Figure 5. As the distance between the seashore and the selected sites increased, the water EC and soil EC decreased gradually. To investigate the effect of site location on the salinity levels, the water EC soil EC at different depths $(5,20,50 \mathrm{~cm})$ were correlated with the distance from the seashore as shown in Table 3. Water EC had the lowest correlation with the distance from the seashore $(\mathrm{R}=-0.48)$. On the other hand, the $\mathrm{EC}$ of the soils in $5 \mathrm{~cm}$ depth had the highest correlation. Regression analysis was done to estimate the soil EC in 5 $\mathrm{cm}$ depth by knowing the distance from the shore using Eqn. 2 (Fig. 6).

$y=-2.7671 x+22.643\left(R^{2}=0.902\right)$

Where $y$ is the EC $(\mathrm{dS} / \mathrm{m})$ of the top layer of soil and $\mathrm{x}$ is the distance from the seashore $(\mathrm{km})$ to the selected site.

\section{Image Analysis}

The image of site 2 is shown as an example in Figure 7. The averaged values of GLI had a strong negative cor-

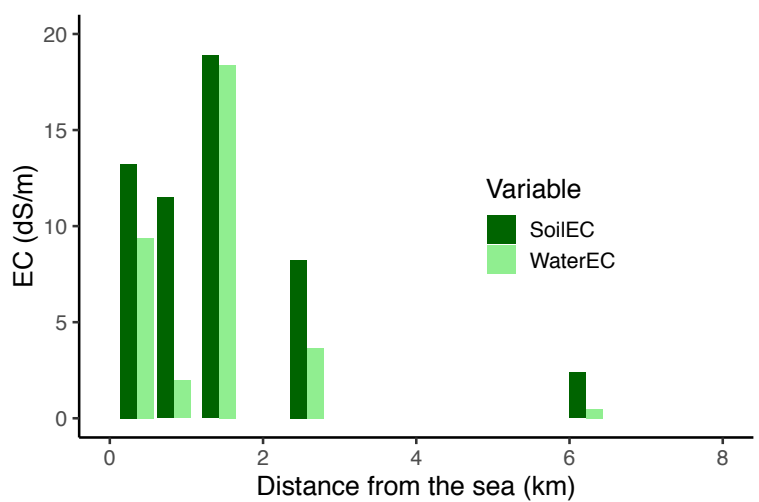

Figure 5. Soil and water EC (dS m-1) of each site (1-5) and site distance from the seashore

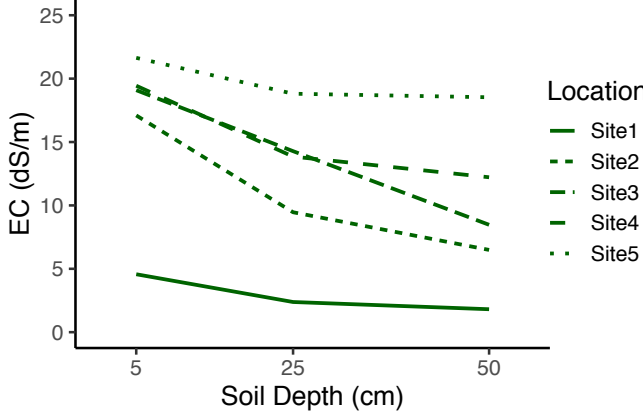

Figure 4. Steps followed to estimate soil and water salinity using GLI

relation with soil EC $(R=-0.96)$ and water $E C(R=-0.92)$. The GLI value of site image can be used to estimate site soil EC (Eqn. 3) and water EC (Eqn. 4) (Fig. 8).

$\mathrm{y}=-2.0737 x+16.15\left(\mathrm{R}^{2}=0.9128\right)$

Where $\mathrm{y}$ is the soil $\mathrm{EC}(\mathrm{dS} / \mathrm{m})$ and $\mathrm{x}$ is the mean value of GLI of the site image.

$y=-2.3241 x+13.887\left(R^{2}=0.8429\right)$

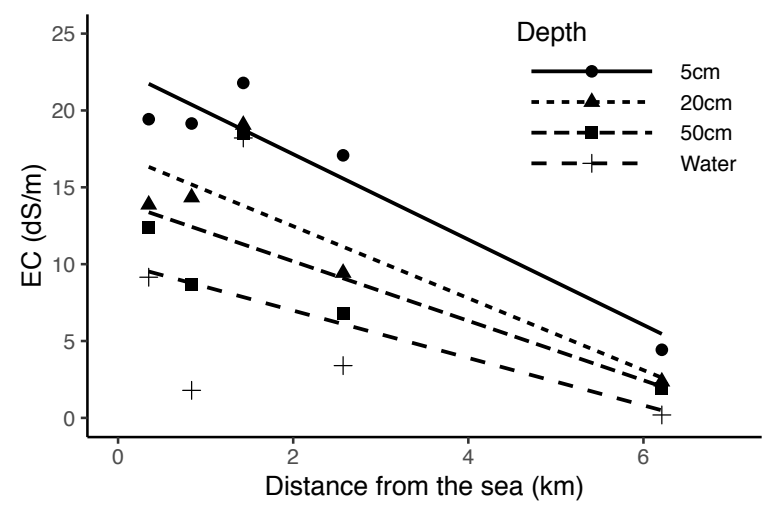

Figure 6. The regression analysis between the sites' distance from the seashore and their water EC and soil EC in different depths $(5,20,50 \mathrm{~cm})$ 

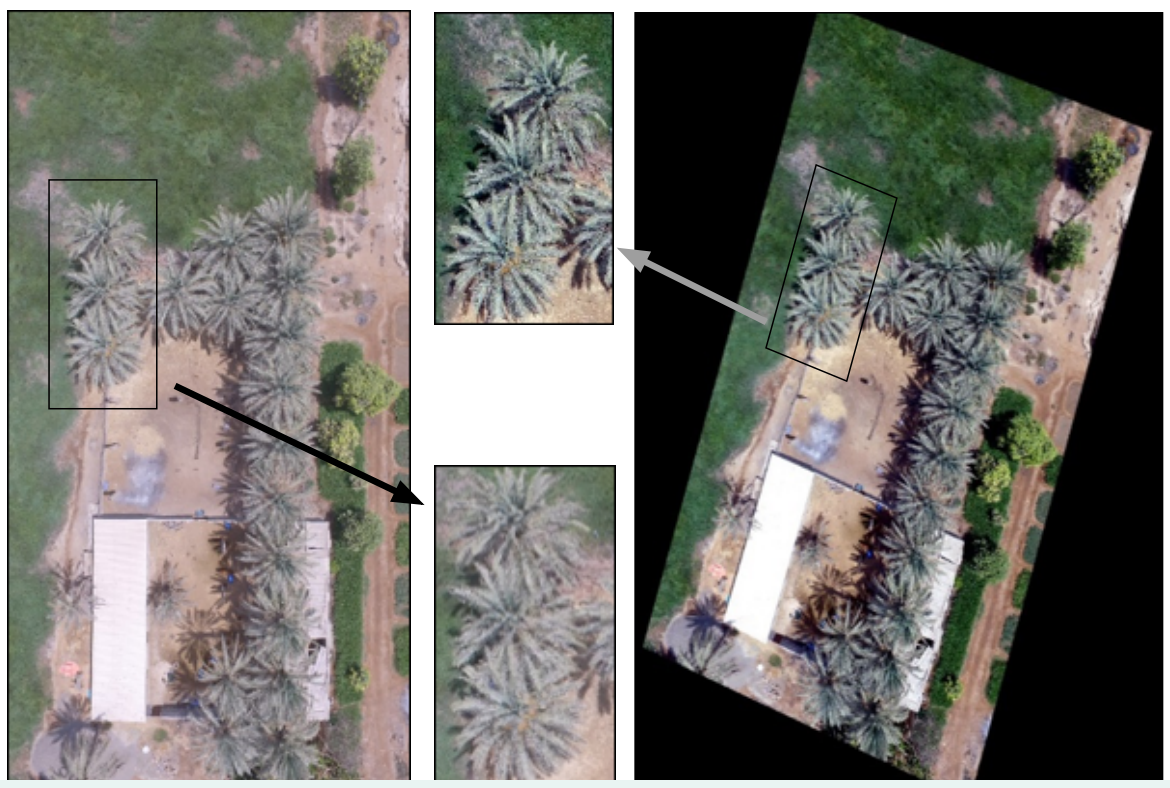

Figure 7. Orthorectification process of site number 2

Where $\mathrm{y}$ is the water $\mathrm{EC}(\mathrm{dS} / \mathrm{m})$ and $\mathrm{x}$ is the mean value of GLI of the site image.

\section{Discussion}

Soil and water salinity decreased as the site is located farther from the seashore (Fig. 5). Site (3) showed relatively unexpected increase in salinity levels, which could be due to the farming practices in the site. All other sites showed clear negative correlation between the distance to the site from the seashore and the salinity levels. On the other hand, an excellent correlation was observed

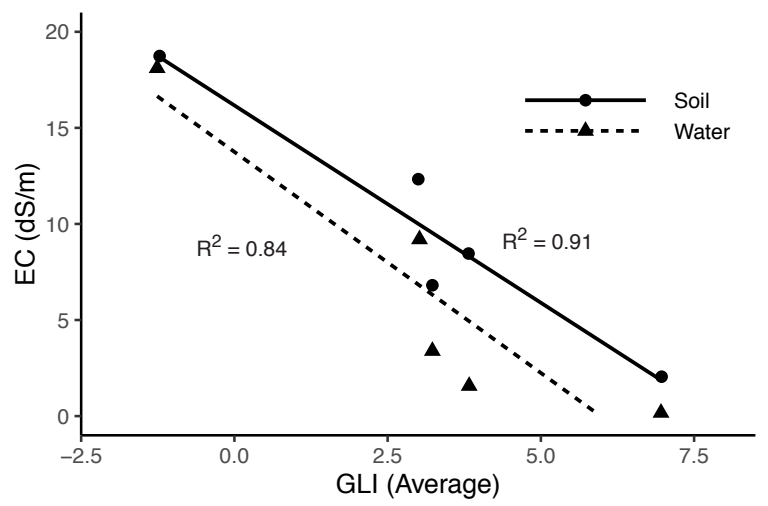

Figure 8. The regression analysis between GLI mean value of each site image and salinity levels of the site while investigating the EC of soils from different depths with the distance from seashore (Table 3). The top soil layers showed the highest values of soil salinity, where that could be due to salt accumulation on the soil surface as reported by Herrero et al. (2003). It also had the strongest correlation $(R=-0.95)$ with distance from the seashore.

The GLI mean values of the images ranged from -1.2 to 6.8. The positive value of GLI was assigned to the green leaves or stems while the negative value was for non-green site objects like; soils, buildings, woods and other non-living items (Louhaichi et al. 2001). In this study it was found that the lowest mean value of GLI was -1.2 for site 1 with the highest salinity level. In general, the results proved that the soil and water salinity had strongly affected the vegetation quantity and quality (greenness), where the mean green value (GLI) declined as the salinity increased. Vegetation Soil Salinity Index (VSSI) were used by Tran et al. (2018) to estimate salinity intrusion from Landsat 8 images with $\mathrm{R} 2=0.6957$. The salinity levels can be estimated by the mean value of GLI with relatively strong values of coefficient of determination, compared to other vegetation indices.

\section{Conclusion}

This research proved the effect of salinity intrusion on site location from the seashore. The five randomly selected sites within the agricultural land belt with different distances from the seashore showed a decline in salinity levels as the site become far from the seashore. The effect of distance on soil salinity could be represented as a regression model. Mainly, this research demonstrated the possibility of using UAV with affordable digital camera to estimate the vegetation cover. The results showed 
a strong negative correlation between salinity levels and GLI as an indicator of vegetation status. Salinity assessment using UAV colour images is coast efficient, timeless and more accurate in relative to field and satellite assessments. Nevertheless, more image processing techniques may strength the possibility of aerial images in estimation of salinity effects on vegetation cover.

\section{Acknowledgement}

The authors thank The Research Council (TRC) of Sultanate of Oman for funding this study (Project No. ORG/EBR/13/004 - Coastal Ecosystem Management for Sustainable Development: A Case study of Al-Batinah Region, Oman). A special thanks for Dr. B. S. Choudri as he was the principle investigator (PI) of the project.

\section{References}

Al-Belushi A. 2003. Desertification in Al-Batinah plain, Sultanate of Oman. PhD Dissertation. Jordanian University, Jordan (in Arabic).

Al-Mulla Y, Ahmed M, Al-Rawahy SA, Hussain N. 2010. Salinity mapping in oman using remote sensing tools: Status and trends. Published in the Monograph on Management of Salt-Affected Soils and Water for Sustainable Agriculture (Mushtaque A, Al-Rawahi SA, Hussain N (eds)). Sultan Qaboos University, Oman. 17-24.

Al-Yahyai R, Khan MM. 2015. Date palm status and perspective in Oman. Date palm genetic resources and utilization. Springer. p.207-240.

Al Barwani A, Helmi T. 2006. Sea water intrusion in a coastal aquifer: A case study for the area between Seeb and Suwaiq, Sultanate of Oman. Journal of Agricultural and Marine Sciences [JAMS]. 11: 55-69.

Bajjali W (2003) Evaluation of the groundwater salinity throughout Sultanate of Oman using GIS. Available at: http://frontpage.uwsuper.edu/bajjali/proj/oman/ o5.htm), last consulted on 23 nov. 2009.

Chianucci F, Disperati L, Guzzi D, Bianchini D, Nardino V, Lastri C, Rindinella A, Corona P. 2016. Estimation of canopy attributes in beech forests using true colour digital images from a small fixed-wing uav. International journal of applied earth observation and geoinformation. 47: 60-68.

Choudri B, Baawain M, Al-Sidairi A, Al-Nadabi H, Ahmed M. 2015a. Relative vulnerability of coastal wilayats to development: A study of Al-Batinah North, Oman. Journal of Coastal Conservation (Springer Science \& Business Media B.V.). 19(1): 51 57.

Choudri BS, Al-Busaidi A, Ahmed M. 2013. Climate change, vulnerability and adaptation experiences of farmers in Al-Suwayq wilayat, Sultanate of Oman. In- ternational Journal of Climate Change Strategies and Management. 5(4): 445-454.

Choudri BS, Baawain M, Ahmed M. 2015b. Review of water quality and pollution in coastal areas of Oman. Pollution Research, Ref 34(2): 229-239.

Choudri, B.S., Baawain, Mahad and Ahmed, Mushtaque (2016). An overview of Coastal and Marine Resources and their Management in Sultanate of Oman, Journal of Environmental Management and Tourism, (Volume VII, Spring), 1(13): 21-32. DOI:10.14505/ jemt.7.1(13).02.

Herrero J, Ba A, Aragüés R. 2003. Soil salinity and its distribution determined by soil sampling and electromagnetic techniques. Soil Use and Management. 19(2): 119-126.

Hunt Jr ER, Doraiswamy PC, Mcmurtrey JE, Daughtry CS, Perry EM, Akhmedov B. 2013. A visible band index for remote sensing leaf chlorophyll content at the canopy scale. International Journal of Applied Earth Observation and Geoinformation. 21: 103-112.

Hussain N. 2005. Strategic plan for combating water and soil salinity in Sultanate of Oman for 2005-2015. Ministry of Agriculture and Fisheries, Oman. 117.

Kwarteng AY, Dorvlo AS, Vijaya Kumar GT. 2009. Analysis of a 27-year rainfall data (1977-2003) in the Sultanate of Oman. International Journal of Climatology. 29(4): 605-617.

Lawley V, Lewis M, Clarke K, Ostendorf B. 2016. Sitebased and remote sensing methods for monitoring indicators of vegetation condition: An Australian review. Ecological Indicators. 60: 1273-1283.

Louhaichi M, Borman MM, Johnson DE. 2001. Spatially located platform and aerial photography for documentation of grazing impacts on wheat. Geocarto International. 16(1): 65-70.

M.A.F. 2013. Oman agricultural census. Muscat, Oman: Ministry of Agriculture and Fisheries pp.

Macfarlane C, Ogden GN. 2012. Automated estimation of foliage cover in forest understorey from digital nadir images. Methods in Ecology and Evolution. 3(2): 405-415.

Mishra DR. 2014. Coastal remote sensing. GIScience \& Remote Sensing. 51(2): 115-119.

Mulder VL, De Bruin S, Schaepman ME, Mayr TR. 2011. The use of remote sensing in soil and terrain mapping - a review. Geoderma. 162(1-2): 1-19.

Rishi P, Mudaliar R. 2014. Climate stress, behavioral adaptation and subjective well being in coastal cities of India. Am J Appl Psychol. 2(1): 13-21.

Tran PH, Nguyen AK, Liou Y-A, Hoang PP, Thanh H. 2018. Estimation of salinity intrusion by using landsat 8 oli data in the mekong delta, Vietnam. 